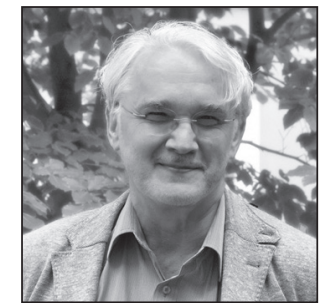

Aleksandras Dobryninas

Centre for Criminology Studies Vilnius University

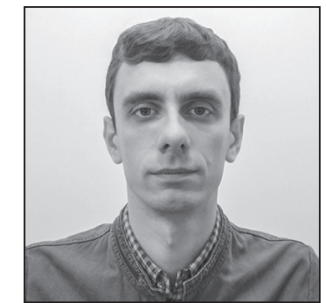

Mindaugas Gilaitis

Centre for Criminology Studies Vilnius University

\title{
Corruption as Presented in the Lithuanian Internet Media'
}

\section{Introduction}

In the modern information age, citizens' perceptions and evaluation of corruption, as well as of many other social problems, are based not only on personal experience but also on the subject's presentation in the mass media. Media have become a natural actor taking part in constructing the public discourse on corruption, shaping attitudes towards corrupt persons, and illuminating and promoting possible measures for tackling and preventing the spread of corruption through society. Although Lithuania belongs to the group of countries in which the level of perceived corruption is assessed as rather positive ${ }^{*_{2}}$, themes related to corruption are very popular in the Lithuanian mass media. Early on, the first diagnostic survey in the 'Map of Corruption in Lithuania' series, conducted regularly since 2001, demonstrated that more than half of the Lithuanian population considered the media to be the source of information that allows forming 'the most reliable opinion about the scale of corruption in Lithuania'. Television was cited as the most reliable source among media-centred means. ${ }^{*} 3$

However, the situation has changed radically since then. While in 2001-2003 the second and third most reliable sources of information were considered to be 'personal experience' and reports from 'friends, acquaintances', the second-place spot behind television in 2016 was occupied by the Internet, which had been statistically 'invisible' in previous years. Personal experience or the experiences of relatives and peers today is considered to be less important than, and not as reliable as, the information obtained via other means, stemming from media sources ${ }^{*}$. These changes provide empirical support to the idea that the majority of Lithuanian society follows the general trends of the information society.

The 'informational' character of Lithuanian society can be illustrated well by the results of the Annual Review of Media Surveys. According to the 2015 survey in this series, in the period 2014-2015, the overall percentage of citizens of Lithuania using the Internet underwent no changes, remaining at $75 \%$. Meanwhile,

1 The article has been prepared within the framework of a project titled 'Social Context of Corruption: An Analysis of Macro, Meso and Micro Level Factors', which is funded by the Research Council of Lithuania (MIP-005/2015).

2 For example, the Transparency International Corruption Perceptions Index (CPI) for Lithuania over the last few years has been around 60 on a scale of 0 ('highly corrupt') to 100 ('very clean'); see Transparency International. Corruption Perceptions Index. Available at http://www.transparency.org/research/cpi/ (most recently accessed on 8.1.2017).

3 Lithuanian Map of Corruption 2001-2005. Vilnius: Eugrimas 2006, pp. 62, 138.

4 Lietuvos korupcijos žemėlapis 2016 ['Lithuanian Map of Corruption 2016']. Available at http://www.stt.lt/documents/ soc_tyrimai/2016_Korupcijos_zemelapis_ataskaita.ppt (most recently accessed on 8.1.2017) (in Lithuanian). 
in contrast, the number of people using the Internet on a regular basis is growing. Over the past three years, the daily-use Internet audience grew the most - from $59 \%$ to $63 \%$. This trend is forecast to continue for the next few years - the number of Lithuanian citizens for whom the Internet is a daily-consumption medium will increase. ${ }^{*} 5$

The average time spent on the Internet each day among the general population is two hours, most of which is spent browsing the news portals, with a little less devoted to using various social networks. According to the 84th Eurobarometer Survey, the Internet is mostly trusted as a source of information in Eastern European countries; the figure is highest in Poland, with Lithuania being in third place. ${ }^{*}$

Taking into account this context, one should not be surprised that in 2016, according to the above-mentioned results from national-level diagnostic surveys focused on corruption, $15 \%$ of the general public, $18 \%$ of public servants, and $23 \%$ of business representatives considered the Internet the most credible source of information on corruption. The corresponding figures in 2008 were only $4 \%, 4 \%$, and $7 \%$, respectively. Although television, as it still does, took a leading role with respect to the perceived reliability of information in general and information on corruption in particular, it is clear that the role of the Internet in informing society about corruption is continuously increasing.

Although analysis of media publications on corruption is becoming a popular academic topic ${ }^{*}$, analysis of Internet-media publications on corruption is rather rare and still demands more insights from academia and discussion of its methodology and results. The intent with the present article is to contribute, at least at local, national level, to filling the gap in research analysing the presentation of corruption-related problems via Internet media. For this purpose, material on corruption published in 2015 via the two main Lithuanian Internet portals, DELFI.lt and Lrytas.lt, have been scrutinised for purposes of revealing their structural and semantic peculiarities. This article presents the methodology of our empirical study and its main results, along with comments on the construction of the virtual image of corruption in the Lithuanian Internet media.

\section{The context and nature of DELFI.It and Lrytas.It's corruption-related publications}

Both portals, DELFI.lt and Lrytas.lt, are classic examples of the 'middlebrows'; i.e., they are engaged with issues that occupy the position between what could be called higher ('quality-ends') and lower ('tabloid') media in terms of standards. ${ }^{*} 8$ DELFI.lt is the leading news portal, receiving the largest number of unique visitors - around 1.2 million during the full-year monitoring period - whereas Lrytas.lt over the same period had around 900,000 visitors. ${ }^{* 9}$ In contrast to the DELFI.lt medium, Lrytas.lt has a paper version also, Lietuvos Rytas, which, according to the market-research company TNS, is the most widely circulated daily newspaper in Lithuania. ${ }^{* 10}$

Since 2007, DELFI.lt has belonged to the Estonian media group Ekspress Grupp, which operates in the three Baltic states and Ukraine and whose activities include publishing, provision of printing services, and production of online media content. Besides running Lithuanian, Russian, Polish, and English versions of

5 Annual review of media surveys 2015. Available at http://www.tns.lt/file/repository/Annual\%20review\%20of\%20Media\%20 Surveys\%202015m.pdf (most recently accessed on 8.1.2017).

6 Trust in media 2016. Available at https://www.ebu.ch/files/live/sites/ebu/files/Publications/EBU-MIS\%20-\%20Trust\%20 in\%20Media\%202016.pdf (most recently accessed on 8.1.2017).

7 For example, see the following recent publications: from the project titled 'Crime As a Cultural Problem: The Relevance of Perceptions of Corruption to Crime Prevention. A Comparative Cultural Study in the EU-Accession States Bulgaria and Romania, the EU-Candidate States Turkey and Croatia and the EU-States Germany, Greece and United Kingdom', with a January 2006 to December 2008 programme period, materials available at http://www.uni-konstanz.de/crimeandculture/ docs/CRIME_AND_CULTURE_Flyer.pdf (most recently accessed on 8.1.2017); from the project titled 'Anti-corruption Policies Revisited: Global Trends and European Responses to the Challenge of Corruption', which ran from January 2012 to February 2017, the publication available at http://anticorrp.eu/wp-content/uploads/2016/09/D6.1.1-Executive-Summary. pdf (most recently accessed on 8.1.2017).

8 On the standards of Lithuanian media, see A. Dobryninas. Virtual Reality of Crime. Vilnius: Eugrimas 2001, pp. $214-215$.

9 Gemius Balti, gemiusAudience, December 2016. Available at http://archive.audience.lt/pages/display/reach (most recently accessed on 8.1.2017).

10 Annual review of media surveys 2015 (see Note 5). 
the Web-based portal, the DELFI group broadcasts DELFI TV. The DELFI group is responsible, in addition, for developing other media content, such as that of Moteris.lt, Cosmopolitan.lt, Panele.lt, 10ooreceptu.lt, and a few others the content of which is (by and large) dedicated to various forms and topics of entertainment.

Lrytas.lt began operation as a Web-based version of the Lietuvos Rytas daily in 1997 and is part of the Lietuvos Rytas Media Group. Since 2006, it has been run as a news Web site company. Two years after these operations commenced, the video service Lrytas.tv was launched, which offers real-time streaming of Lietuvos Rytas television. Lrytas.lt consists of several sub-portals that are dedicated to specific topics, such as advertisements, animals, and recipes. ${ }^{* 11}$

As was mentioned above, the monitoring period for our content analysis extended from 1.1.2015 to 31.12.2015. The articles have been selected by reference to nine keywords: 'corruption', 'corrupted', 'bribe', 'bribery of intermediary', 'abuse of office', 'anti-corruption', 'nepotism', 'conflict of interests', and 'transparency'. The articles selected were analysed with regard to the following indicators:

- publication date and time

- the title of the article

- author's name

- author's gender

- $\quad$ place of publication (in terms of first-level and second-level rubrics)

- information sources (main and secondary)

- whether the publication title matches its content

- whether the headline makes reference to the theme of corruption

- the mood (sentiments) of the presentation (positive, negative, or neutral)

- whether the publication is of analytical or instead descriptive type

- what kind of corruption is referred to (bribery, abuse of office, broker bribery, nepotism, or other)

- whether the publication refers to any anti-corruption activity (prosecution, prevention efforts, education, or other)

In 2015, the two news portals published similar quantities of publications related to matters of corruption: 1,312 articles (or 49\% of all selected publications) came from DELFI.lt and 1,367 (51\%) from Lrytas.lt. For some of these, however, corruption was not the main topic, and the content overall had little, if anything, to do with the problems of corruption in society. In addition, some of the publications identified were not related to Lithuania, addressing corruption issues primarily in other countries. Hence, for further analysis, the articles about corruption in Lithuania were selected.

Of the 819 publications chosen for further analysis, 306 (37\%) were published by DELFI.lt and 513 (63\%) by Lrytas.lt. As one can see, the number of articles devoted to the problem of corruption in Lithuania is considerably lower than the initial quantity of publications found to make general reference to corruption. The reduction was significantly greater in the case of DELFI.lt (more than four times) than in that of Lrytas.lt (a little over two and a half times). This can be partly explained by the fact that DELFI.lt expresses stronger interest in corruption problems in foreign countries, especially in Russia and Ukraine (within the context of all the publications on corruption). In comparison with DELFI.lt, Lrytas.lt paid more attention to the domestic problems and less to the international ones (again, when the context of evaluation covers all the publications on corruption).

Further analysis of the selected publications revealed that in 2015, the two Internet portals shared the same media policy with regard to the collection and the processing of information on matters of corruption. With both media portals, the majority of publications referred to their own sources of information as the main one (63\% for DELFI.lt, and 71\% for Lrytas.lt). Also, for both portals the second main source of information was the news agency Baltic News Service (BNS). It was mentioned in $27 \%$ of the DELFI.lt publications and in $21 \%$ of the Lrytas.lt pieces (see Figure 1 ).

11 Mapping digital media: Lithuania. Available at https://www.opensocietyfoundations.org/sites/default/files/mapping-digitalmedia-lithuania-20110923.pdf (most recently accessed on 28.1.2017); Baltic media health check 2014-2015. Available at https://www.sseriga.edu/download.php?file=/files/news/baltic_media_health_check_2015.pdf (most recently accessed on 28.1.2017). 

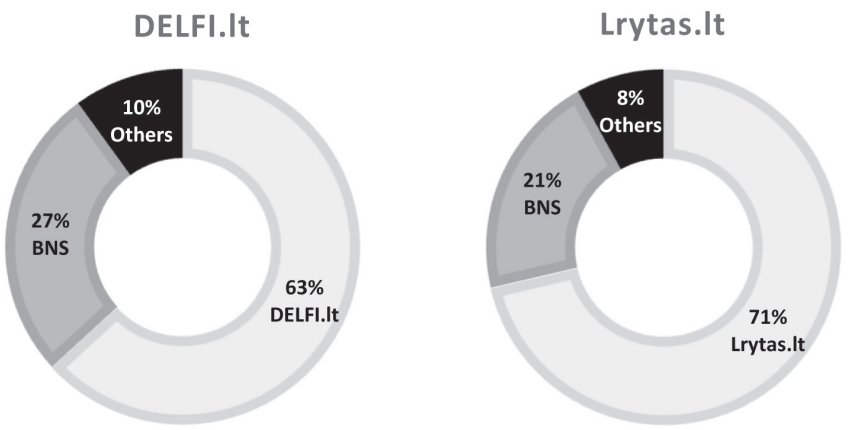

\section{Figure 1. The main sources of information for corruption-related articles of DELFI.lt and Lrytas.lt.}

In both portal services, the corruption-related information was hierarchically organised. On the most general ('first') level, the absolute majority of corruption-related publications were situated within such popular rubrics as 'DELFI news' and 'Daily news' in the case of DELFI.lt ( $86 \%$ of all publications) and 'Lithuanian daily' and 'Lrytas.lt' for Lrytas.lt (94\% of all publications). However, the themes forming the context for corruption-related articles under second-level rubrics were different:
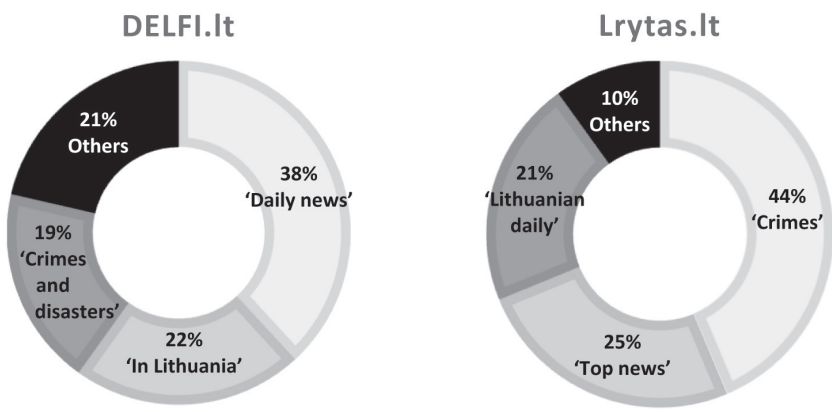

\section{Figure 2. The second-level rubrics for corruption-related publications of DELFI.lt and Lrytas.lt.}

As one can see from Figure 2, corruption-related publications from Lrytas.lt were often linked with criminal events ( $44 \%$ of all publications), while the DELFI.lt publications were connected to 'daily' ( $38 \%$ of all publications) rather than to 'criminal' (19\%) events. It appears that corruption-related publications were marked as on 'criminal' matters more often by Lrytas.lt than by DELFI.lt, where they were usually interpreted as referring to 'ordinary, daily' events.

The results of the analysis demonstrate also that the portals considered were similar in their attempt to represent the content of the publications accurately in their headlines: $97 \%$ of the DELFI.lt publications and $96 \%$ of the Lrytas.lt publications had headlines that corresponded to their content. Furthermore, a healthy share of these headlines (63\% in DELFI.lt and a similar $66 \%$ in Lrytas.lt) referred to the theme of corruption, making them easier to spot for an eye that is hungry for 'hot' news, which, thereby, can contribute to the attractiveness of these publications for a significant proportion of possible readers ('clickers'). Also, as is typical for 'middlebrows', both Internet portals showed a certain pattern in the proportion of analytical to descriptive articles on corruption: $12 \%$ to $88 \%$ for DELFI.lt and $16 \%$ to $84 \%$ for Lrytas.lt.

The next important issue is their reference to the concrete corruption problems in society. Formally, by comparing the above-mentioned numbers of publications from both sources with the number of prosecutions for acts of corruption as cited by official statistical data sources ${ }^{* 12}$, it is possible to predict the level of 'overrepresentation' of corruption by Lithuanian Internet media, a phenomenon usually found with 'crime

12 In 2015, Lithuania's national anti-corruption body, the Special Investigation Service (SIS), started 77 pre-trial investigations of corruption issues; in the same period, 110 persons were accused and sentenced by Lithuanian courts for related crimes. See section 'Nusikaltimų tyrimai' ('Corruption Investigation') on STT's Web site at http://www.stt.lt/lt/menu/tyrimai-iranalizes/ (most recently accessed on 2.1.2017) (in Lithuanian). 
news"*13. Indeed, as one can observe, the number of publications is disproportionately larger than the number of corruption cases. However, 'dark figures', not represented in official statistics, are a well-known phenomenon: presenting institutional efforts to control social problems (e.g., corruption) rather than providing a 'real' account based on precise measurement of corresponding facts. From this perspective, analysis of the 'structure' of corruption-related publications proceeds better via comparison with the results from various diagnostic surveys on corruption, which can shed additional lights on corrupt interactions in society, as well as on their possible control and prevention.

Closer analysis of the selected publications allowed us to observe that, as Figure 3 shows, the two portals' publications are about the same in their breakdown by the main forms of corruption. The absolute majority of publications from both portals consists of articles devoted to issues of bribery (58\% in DELFI.lt and 59\% in Lrytas.lt). The next most visible topic is abuse of office (19\% in DELFI.lt and 23\% in Lrytas.lt). The two also were similar in their percentage of publications on solicitation or 'bribery of intermediary' ( $5 \%$ in DELFI.lt and 6\% in Lrytas.lt) and nepotism (4\% and 3\%, respectively).

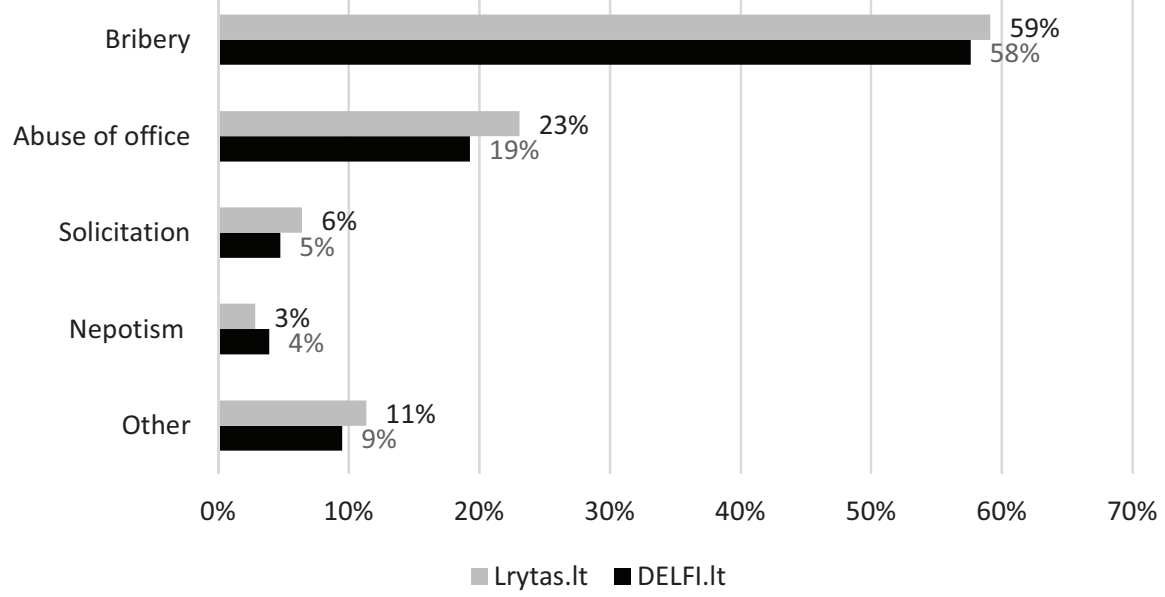

Figure 3. The percentage of DELFI.lt and Lrytas.lt articles devoted to the various forms of corruption.

At first glance, these results perfectly illustrate one of the biggest problems of Lithuanian society - bribery. For example, they correspond to the findings of the most recent Global Corruption Barometer survey, which revealed that in 2013 about $24 \%$ of households reported having paid a bribe (the second worst result in Europe) ${ }^{*} 14$. However, when these findings are compared with the 'Map of Corruption in Lithuania 2016' results, one can notice that this structure only partially corresponds to the public's evaluations of how much the various types of corruption permeate society. Thus, one sees that $75 \%$ of respondents in 2014 marked bribe-giving as a 'common' or 'very common' phenomenon in society and put it in first place among the forms of corruption listed, followed by taking bribes (74\%) and engaging in nepotism (68\%). By 2016, however, public attitudes with regard to the pervasiveness of various forms of corruption had changed: nepotism took first place (74\%), while the forms of bribery mentioned above dropped to third and fourth place (72\% for bribe-giving and 71\% for bribe-taking). Abuse of power was ranked in ninth place in 2014 (51\%) and occupied sixth place in $2016(61 \%) .{ }^{*} 15$ This breakdown from the survey results is quite different from that of our media data from 2015, as presented in Figure 3: both portals paid less attention to the problem of nepotism and more to that of abuse of office. It seems that the Lithuanian population had a slightly different vision of the problem of corruption in society than was visible through the lens of Internet media.

A difference between the two portals is visible in relation to the presentation of anti-corruption measures, such as criminal prosecution, prevention work, and education. These measures are the key elements of the national anti-corruption policy and are often used in anti-corruption rhetoric by politicians and lawenforcement professionals. In general, anti-corruption measures were mentioned in 89 of the DELFI.lt

13 See A. Dobryninas (see Note 8), pp. 174-182.

14 C. Pring. People and Corruption: Europe and Central Asia 2016. Global Corruption Barometer. Transparency International 2016, p. 28.

15 Lietuvos korupcijos žemélapis 2016 (see Note 4). 
articles (29\% of all DELFI.lt publications analysed) and in 267 articles from Lrytas.lt (52\% of all Lrytas.lt publications analysed). The numbers for publications in which anti-corruption measures were mentioned are presented below, in Figure 4, where they are broken down by type.

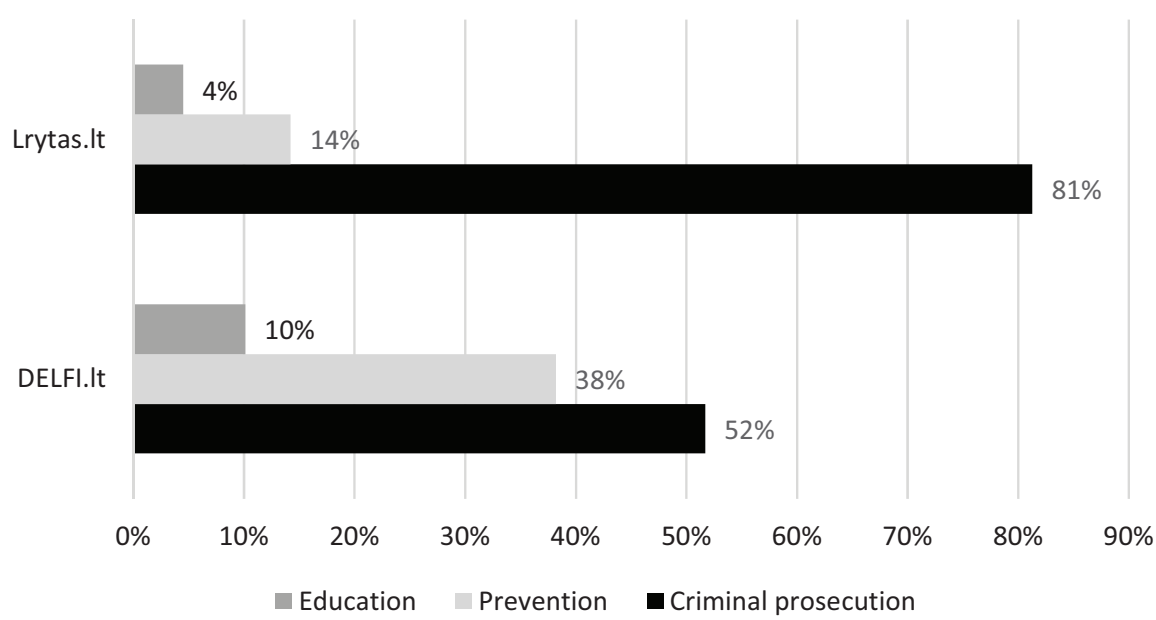

Figure 4. The main anti-corruption measures mentioned in DELFI.lt and Lrytas.lt pieces.

It is clear that both media portals' materials mentioned criminal prosecution more often than prevention or education. At the same time, it is obvious also that the share of Lrytas.lt publications referring to criminal prosecution was much greater than the corresponding DELFI.lt figure, and the share of Lrytas.lt publications making reference to prevention and education was significantly smaller than DELFI.lt's equivalent. It is worth noting that, according to the Map of Corruption in Lithuania 2016 data $^{*} 16,50 \%$ of respondents held that criminal prosecution is the most effective measure against corruption, $27 \%$ cited prevention, and $11 \%$ education. From this perspective, the presentation of anti-corruption measures by DELFI.lt mirrors public attitudes towards these issues more closely than Lrytas.lt does.

To what extent the observed peculiarities of the presentation of corruption-related information via Lithuanian Internet portals could influence the perception of corruption among their visitors is a matter for further sociological and psychological research. However, under the current approach, simple sentiment analysis allows evaluation, albeit indirect, of the emotional impact that the publications considered could have had on potential readers. Results of such analysis are presented in Figure 5. The distribution of attitudes towards the most effective measures against corruption is a closer match to the sentimental character of publications in DELFI.lt than to Lrytas.lt articles.

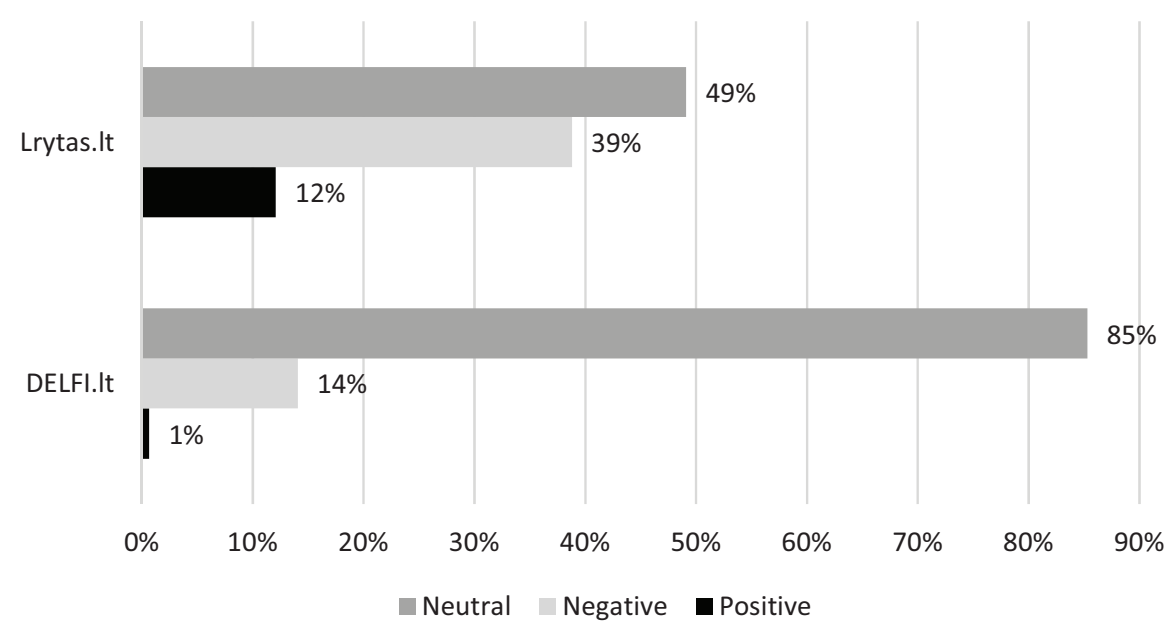

Figure 5. Sentimental aspects of the corruption-related publications of DELFI.lt and Lrytas.lt. 
Firstly, it is noticeable that both Internet portals preferred to use neutral mode in their writing on the corruption-related matters. A possible explanation for this result might be found by considering the typical (i.e., neutral) attitude of the Lithuanian population towards bribery. While, according to the results of the national representative survey entitled 'Map of Corruption in Lithuania 2016'*17, already mentioned, the attitude towards corruption held by the majority of respondents in general was negative (65\% of respondents considered corruption to be an obstacle to a better personal life and $78 \%$ to the well-being of society), their attitude towards bribery was strikingly different: $68 \%$ of the respondents (69\% in 2014) insisted that bribes 'help to solve the problem', whereas 40\% (48\% in 2014) 'would give a bribe in order to solve a problem'. One shall not be surprised that in such a social context the information about cases of bribery and similar acts could be associated with an ordinary (i.e., not unusual or abnormal) phenomenon.

Simultaneously, it is worth noting that publications from Lrytas.lt were more emotionally coloured than DELFI.lt's, with both negative (39\% for Lrytas.lt as opposed to $14 \%$ for DELFI.lt) and positive attitudes (12\% and $1 \%$, respectively) being more prevalent in Lrytas.lt articles. This can be explained by the fact that, as was shown above, Lrytas.lt provided criminally-oriented framing for corruption-related information while in DELFI.lt this kind of information was framed as an element of day-to-day life. Since the time of É. Durkheim, it has been recognised that criminal events are a strong emotional trigger for social solidarity ${ }^{*}{ }^{*}$; accordingly, their prevalence in media publications inevitably renders the information that is presented less neutral and more emotionally flavoured.

\section{Semantic analysis of the corruption-related publications from Lithuanian Internet media}

Examination of the general semantic structure of corruption-related information is another angle for research, which can be treated as supplementary to the starting point for the foregoing analysis. Given that the media play an important role in shaping and initiating public discussions of various social issues ${ }^{* 19}$, it is of crucial importance and interest to learn what the basic referents of messages on corruption are conveying to the public audience via the various media.

The semantic analysis of corruption-related publications in both the DELFI.lt and the Lrytas.lt service was carried out by means of the quantitative content analysis software HAMLET II 3.0. ${ }^{* 20}$ The program allows one to calculate frequencies for the selected words and their binary combinations within the semantic units (in this case, at sentence level) across the array of publications. The analysis of words' frequencies enables figuring out the combinations of words (termed 'clusters') that were most often used across the corpus of publications in presenting cases of corruption.

The cluster analysis has been carried out separately for two arrays of publications: from DELFI.lt (135,211 words; 9,923 sentences) and from Lrytas.lt (183,600 words; 12,626 sentences). The first step in a quantitative analysis of textual data is to compile a dictionary consisting of a set of terms that would be conceptually relevant for the analysis in question. In the body of properly selected publications, the words that get used most often should be semantically connected to the topic of research: in this case, the theme of corruption.

A compilation of the most relevant terms has been created through use of HAMLET's 'wordlist' function. Based on the word-list analysis, two semantic dictionaries were created, separately for the DELFI.lt and Lrytas.lt textual compendia.

\footnotetext{
Ibid.

18 See E. Durkheim. The Division of Labour in Society. London: The Macmillan Press Ltd 1984.

19 See A. Dobryninas et al. Perception of Criminal Justice in Society. Vilnius: Baltijos kopija 2014.

20 More details about HAMLET II 3.0 can be found at http://apb.newmdsx.com/hamlet2.pdf (at least as recently as 19.1.2017).
} 
Table 1: The vocabularies for the DELFI.lt and Lrytas.lt text arrays

\begin{tabular}{|l|l|l|l|}
\hline DELFI.lt & \multicolumn{2}{c|}{ Lrytas.lt } \\
\hline \multicolumn{1}{|c|}{ Initial cluster name } & Main term²1 & \multicolumn{1}{c|}{ Initial cluster name } & Main term \\
\hline 'Foreign countries and cities' & vRusij & 'Foreign countries and cities' & Rusij* \\
\hline 'Lithuania' & VLietuv & 'Lithuania' & vLietuv \\
\hline 'Lithuanian politicians' & lppolitik & 'Lithuanian politicians' & lppolitik \\
\hline 'Officials' & pareigyb & 'Officials' & pareigyb* \\
\hline 'Law-enforcement institutions' & ttarnyb & 'Law-enforcement institutions' & ttarnyb \\
\hline 'Law-enforcement personnel' & pareiguuun & 'Law-enforcement personnel' & pareiguuun* \\
\hline 'Corruption' & kysh & 'Corruption' & korupcij* \\
\hline 'Finance' & pajam & 'Finance' & grynais* \\
\hline 'Illegal activities' & neteiseeet & 'Illegal activities' & neteiseeet* \\
\hline 'Prevention' & prevencij* & 'Prevention' & prevencij* \\
\hline 'Control' & control & 'Control' & ikiteismin* \\
\hline 'Official institutions' & seim & 'Official institutions' & seim* \\
\hline 'Political parties' & partij & 'Political parties' & sartij \\
\hline 'Business' & versl & 'Business' & vbank \\
\hline
\end{tabular}

Each initial-cluster name in the above vocabularies is an abstract designator for the main term and its synonyms, which are presented at the top in the word list (i.e., are most frequently used in the text). For example, the cluster name 'Finance' in the DELFI.lt vocabulary stands for the main term 'pajamos' (Lithuanian for 'income') and its synonyms, meaning 'bank', 'dollar', 'euro', and 'litas', that were found in the word lists ${ }^{*}{ }^{22}$. Once the semantic 'fine-tuning' of clusters has been carried out, it emerges not only that both dictionaries are constituted by the same number of clusters but also that the clusters themselves (the categories they signify) are semantically identical. However, this does not allow one to conclude that the two news portals are exactly alike semantically, for identity of clusters does not imply identity of the terms (or their number) used in the publications. But it does show that on a more general level, matters of corruption were presented by using the same categorical framework.

Completed by HAMLET, the calculation of words' frequencies on the basis of the compiled dictionaries across the compendia of selected publications (separately for DELFI.lt and Lrytas.lt) allowed revealing two groups of clusters ${ }^{*}{ }^{23}$ for each portal. The peculiarities of the clusters constructed can be seen from further semantic analysis.

DELFI.lt

Cluster 1: 'Prevention', 'Lithuanian politicians', 'Official institutions', ‘Business', 'Officials', 'Political parties', 'Lithuania'.

Cluster 2: 'Illegal activity', 'Crime control', 'Corruption', 'Law-enforcement personnel', 'Lawenforcement institutions', 'Finance', 'Foreign countries'.

As one can see, the sub-clusters from the domain of 'Cluster 1' are related to the macro-level social context of corruption and associated with political and business activities on the national level. In turn, the subclusters from the domain of 'Cluster 2' are connected to the law-enforcement agencies and their activities. The semantic particularities of these sub-clusters are made visible in Figure 6 and Figure 7, which represent their hierarchical structure.

21 'Main term' is a linguistically modified term for HAMLET purposes that is created by using the root (plus asterisk) of each of the most frequent words in the textual corpus, which, together with its 'synonyms', refers to the content of the initial cluster.

22 All of the terms that have been used in the analysis were taken in their original linguistic forms.

23 Word clusters' significance level for inclusion: 0.01 . 


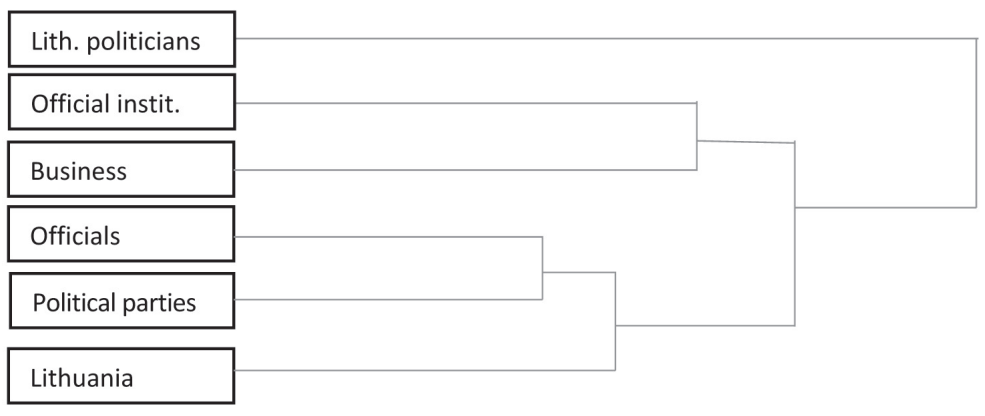

Figure 6. The core elements of Cluster 1 for DELFI.lt.

In Cluster 1, corruption issues are covered in the context of the activities of political organisations and Lithuanian officials, both at national and at local level. Two examples from DELFI.lt news can be cited in this connection:

It is alleged that, during the first tour of elections, at night, the Labour Party representative, after sending the members of the electoral commission from the other parties home, invited another Labour Party member, from another electoral district, and, as suspected, filled in 55 blank ballots with the surnames of the Labour Party representatives. (DELFI.lt, at http://www.delfi.lt/news/ daily/lithuania/alytuje-itarima-idel-rinkimu-balsu-klastojimo.d?id=67402728 - authors' translation.)

The parties that have abused the roots of politics - justice - act as gangs robbing from the city (state) budget. However, they represent only $4 \%$ of the Lithuanian population. It appears to be a suitable time to send these new nomenklatura parties - first of all, at municipality level - to a deserved rest. (DELFI.lt, at http://www.delfi.lt/news/ringas/politics/e-dzezulskis-duonys-ar-perlausime-sistema.d?id=67074380 - authors' translation.)

It is worth noting that, although the notion of prevention is related to the core elements of Cluster 1, the link is statistically weak and is insignificant within the textual corpus of DELFI.lt publications.

Cluster 2 and, especially, the three sub-clusters 'Law-enforcement personnel', 'Law-enforcement institutions', and 'Corruption' indicate an intention to present corruption control as being a matter of lawenforcement activities. Here are some illustrative examples from DELFI.lt:

The court has declared that fines must be paid within two years. The court has also confiscated from customs officers various sums of money - 30 or 60 litas - which had been revealed during operations. Most of the custom officers are temporarily suspended from their duties; all convicted persons are ordinary civil servants. (DELFI.lt, at http://www.delfi.lt/verslas/transportas/neteisetas-rinkliavas -eme-medininku-muitininkai-nubausti-beveik-puses-milijono-euru-baudomis.d?id=66814836 authors' translation.)

After the new search at Order and Justice party headquarters and in the Ministry of the Interior and related institutions that had been carried by the Special Investigation Service (SIS) officers, [...] new allegations have been released with regard to an estimated five more persons. (DELFI. lt, at http://www.delfi.lt/news/daily/lithuania/po-kratu-partijos-tvarka-ir-teisingumas-bustinejenauji-itariamieji.d?id=66844144 - authors' translation.)

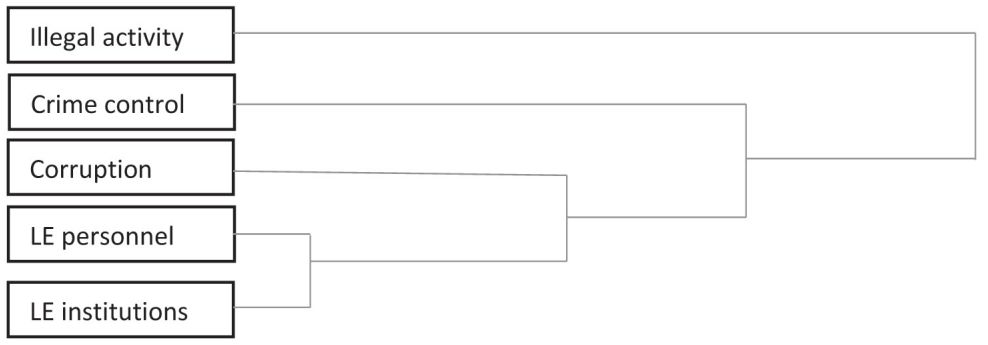

Figure 7. The core elements of Cluster 2 for DELFI.lt. 
The sub-cluster under the title 'Foreign countries' is linked with another sub-cluster - 'Finance'. However, statistically the link does not meet the necessary level for inclusion as significant and hence cannot be taken into consideration as a valid element for further analysis.

Lrytas.lt

Cluster 1: 'Prevention', 'Lithuanian politicians', 'Official institutions', 'Political parties'.

Cluster 2: 'Illegal activity', 'Crime control', 'Corruption', 'Law-enforcement personnel', 'Lawenforcement institutions', 'Finance', 'Officials', 'Business', 'Foreign countries', 'Lithuania'.

The clusters representing Lrytas.lt are similar to those of DELFI.lt. The sub-clusters belonging to Cluster 1 tie prevention issues with Lithuanian political and government institutions. The sub-clusters from Cluster 2 refer primarily to law-enforcement activities for controlling corruption. However, in a difference from DELFI.lt, in Lrytas.lt this set of sub-clusters is connected with institutional, business, and financial issues. The dendrograms below (in Figures 8 and 9) reveal the hierarchical composition of the elements of both clusters.

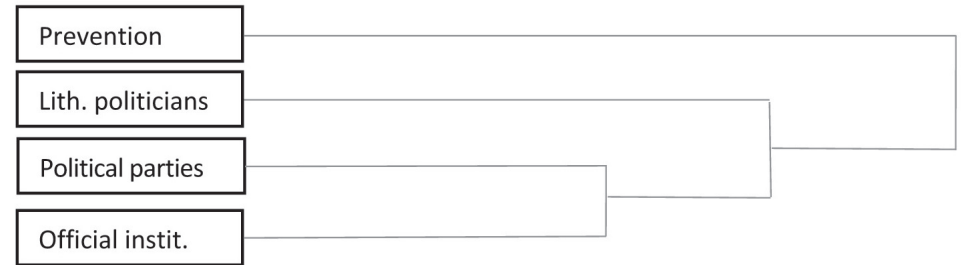

Figure 8. The structure of Cluster 1 for Lrytas.lt.

Similarly, as in the case of DELFI.lt, the semantic analysis of Cluster 1 revealed that prevention issues in Lrytas.lt publications usually appeared in the political-institutional context. However, the links between sub-clusters within Cluster 1 are statistically weak; therefore, the following examples represent rare cases of the links between the sub-clusters in the overall context of the publications of Lrytas.lt:

That would most likely be the most dangerous violation of the law, which, if proved, would probably lead to the nullification of election results. Obviously, these cases should be investigated by law enforcement, whereas Parliament should take care of the rules of law that would prevent fictitious voters' migration. (Lrytas.lt, at http://lietuvosdiena.Lrytas.lt/aktualijos/isankstinis-balsavimassukele-itarimu.htm - authors' translation.)

While looking forward, the president of the International Chamber of Commerce has noted that it would be useful to form a guide for corruption prevention in business, which could be prepared by the associated business structures and the Special Investigation Service. According to V. Sutkus*24, this guide could become a useful indicative document for both companies and the society. (Lrytas. lt, at http://verslas.Lrytas.It/rinkos-pulsas/verslo-zvilgsnis-i-korupcijos-prevencija.htm - authors' translation.)

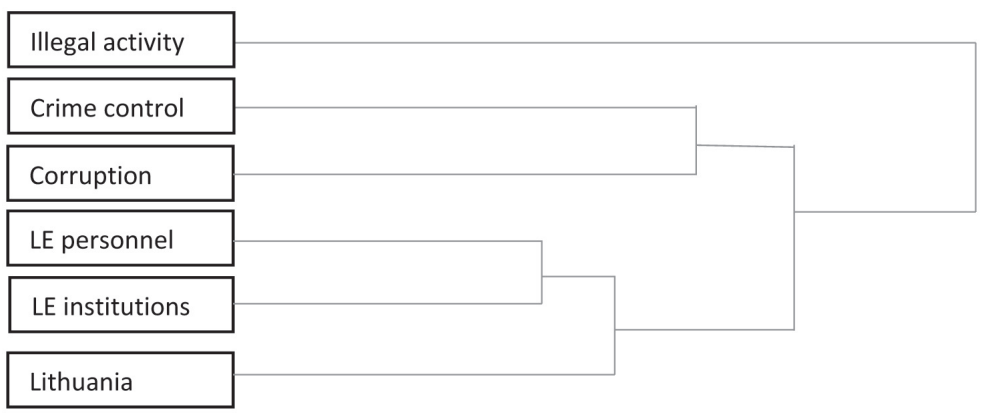

Figure 9. The core elements of Cluster 2 for Lrytas.lt.

24 V. Sutkus is an individual who was interviewed by the Lrytas.lt journalist. 
Irrespective of the fact that 'civil' elements are present in Cluster 2, the statistically reliable core elements consist of 'criminal'-oriented sub-clusters: the 'Corruption' sub-cluster is more closely related to the 'Crime control' sub-cluster, and this link in its turn is connected with the 'Lithuanian law enforcement' sub-cluster. The following examples extracted from Lrytas.lt illustrate this interconnection:

While continuing the pre-trial investigation of the corruptive actions of the representatives of a pharmaceutical company and the doctors belonging to the medical institutions from various countries, the officers from the Special Investigation Service have also raised allegations pertaining to large-scale bribery and fraudulent accounting against two more persons - the director of the pharmaceutical company and the development manager. (Lrytas.lt, at http://lietuvosdiena.Lrytas.lt/ kriminalai/stt-pareikst-iitarimai-farmacijos-bendroves-vadovams.htm - authors' translation.)

The Chief Official Ethics Commission has a list consisting of 33 persons who are suspected of violating public and private interests, while investigating the possible corruption scandal at Druskininkai Aquapark. However, its representatives cannot begin the investigation so long as the pre-trial investigation carried out by the Special Investigation Service is not finished. (Lrytas.lt, at http:// lietuvosdiena.Lrytas.lt/aktualijos/isivelusiu-i-druskininku-vandens-parko-skandala-33-asmenys. htm - authors' translation.)

As one can see, the semantic analysis of the corruption-related publications issued by DELFI.lt and Lrytas.lt allows concluding that corruption-linked issues are presented in a very similar way between the two Internet portals. More specifically, the phenomenon of corruption is virtually criminalised; i.e., by and large, it is considered to be a matter for law-enforcement activities (in the Lrytas.lt materials, this feature is presented in a more obvious manner) whereas the political, governmental, or business aspects appear to be less important, with the articles not speaking about the prevention-of-corruption topic, which is rather marginalised.

\section{Conclusions}

The growing role of Internet media has become a significant factor in providing vital information to the members of society, as well as in initiating and shaping public discussion of the most acute social problems. Corruption, being one of the most discussion-prone topics in contemporary communities, is also positioned as among the most popular themes of the Internet media. As recent studies have shown, in Lithuania the Internet media rapidly became one of the most relied-upon sources of corruption-related information.

Our structural and semantic analysis of the corruption-related publications of the two most influential Internet portals in Lithuania, DELFI.lt and Lrytas.lt, has revealed that they both fit the so-called middlebrows position: the articles in general are more descriptive than analytic, and the mode of publications is rather more neutral than emotional. In comparison of the results of the study with the findings from the diagnostic survey Map of Corruption in Lithuania 2016, it is important to notice that both Internet portals reflected the public concern about the spreading of bribery in Lithuanian society and paid close attention to this topic in their publications. However, at the same time, they both underrepresented the problem of nepotism, which, according to the survey results, is another acute corruption problem in society.

The analysis of the selected publications has revealed, in addition, a tendency toward virtual criminalisation of corruption, with framing of corruption problems in a criminal-justice context (more prevalent with Lrytas.lt, less so with DELFI.lt). In consequence of said framing, important elements of anti-corruption policy - prevention and education - were underrepresented in the publications examined. In contrast, both portals paid much more attention to criminal prosecution, which, as the results of the diagnostic survey have shown, has also been cited as a favourable anti-corruption measure by the majority of Lithuania's population.

The study reported upon here cannot be treated as a comprehensive analysis of the coverage of corruption by the Lithuanian Internet media. It concentrated on the most commonly present and visible (in a quantitative sense) aspects of the presentation of corruption in a relatively narrow domain (two Internet portals) and in the short term (a one-year publication period). Obviously, new research in this area could address itself to a broader space of information sources, including social networks, and consider dynamic changes in the context of media presentations, and it could embark upon their deeper quantitative and qualitative analysis and interpretation. 